\title{
Pengembangan Model Matematika Dinamika Perokok Di Kota Bogor
}

\author{
Embay Rohaeti ${ }^{1, \text { a) }}$ dan Ani Andriyati ${ }^{2, \text { b) }}$ \\ ${ }^{1}$ Program Studi Matematika FMIPA Universitas Pakuan \\ ${ }^{2}$ Program Studi Matematika FMIPA Universitas Pakuan \\ a)email:embayrohaeti@gmail.com \\ ${ }^{b)}$ email: ani.andriyati2@gmail.com
}

\begin{abstract}
Abstrak
Masih tingginya kasus perokok di Kota Bogor menjadi alasan bagi masyarakat, praktisi kesehatan, pemerintah untuk mengambil langkah dan kebijakan yang tepat dalam mencegah meluasnya perokok di Kota Bogor. Sebagai salah satu bidang ilmu, matematika turut memberikan peranan penting dalam mencegah meluasnya perokok yaitu melalui model matematika terkait peningkatan jumlah perokok. Pada model matematika dinamika perokok, individu dalam populasi $(N)$ dibagi ke dalam empat kelompok yaitu kelompok perokok potensial $(P)$, kelompok perokok kadang-kadang $(L)$, kelompok perokok berat $(S)$, dan kelompok mantan perokok (Q). Model matematika dinamika perokok dikembangkan dengan melibatkan faktor efikasi diri untuk berhenti merokok, sehingga model matematika yang terbentuk tersebut diharapkan dapat lebih mendekati keadaan nyata dinamika perokok di Kota Bogor, langkah selanjutnya model matematika tersebut dianalisis secara analitik dan numerik. Berdasarkan hasil yang diperoleh bahwa pada kondisi bebas perokok, jumlah perokok kadang-kadang akan mendekati nol pada 16 tahun yang akan datang dan pada kondisi marak perokok, jumlah perokok berat terus meningkat dari tahun ke tahun. Hal ini menunjukkan bahwa setelah adanya faktor efikasi diri untuk berhenti merokok jumlah perokok di Kota Bogor mengalami penurunan tetapi tidak akan mencapai nol.
\end{abstract}

Kata kunci: perokok, efikasi diri, model matematika

\section{Publikasi Ilmiah Matematika}

\section{Abstract}

The case of smoker is still being a high case in Bogor. It is the reason for the public, health practitioners, and Government to take steps and proper policy in preventing widespread smokers in Bogor. As one of the fields of science, mathematics provides a vital role in preventing widespread smokers through mathematical models related increase in the number of smokers. On mathematical model of the dynamics of smokers, individuals in the population $(\mathrm{N})$ were divided into four groups, namely the Group of potential smokers (P), the Group of smokers sometimes (L), heavy smoker Group (S), and a group of former smokers (Q). Mathematical model of the dynamics of the smokers developed by involving self-efficacy factor to quit smoking, so that mathematical models that formed was expected to be closer to the real state dynamics of smokers in Bogor, the next step is the mathematical model will be analyzed analytically and numerically. Based on the results on non-smoking condition, the number of smokers sometimes will approach zero at the next 16 years and on the conditions of many smokers, the number of heavy smokers continue to increase from year to year. This indicates that the existence of self-efficacy factor to quit smoking made the number of smokers in Bogor decline but it would not reach zero.

Keywords: smoker, self-efficacy, mathematical model 


\section{Pendahuluan}

Kebiasaan merokok di Kota Bogor bukan hanya pada kalangan remaja saja bahkan tidak sedikit dari kalangan siswa sekolah dasar. Dampak kerugian yang ditimbulkan rokok bukan hanya masalah kesehatan saja tapi juga moral dan finansial. Kebiasaaan merokok telah terbukti berhubungan dengan sedikitnya 25 jenis penyakit pada berbagai organ tubuh, selain pada orang yang merokok (perokok aktif), penyakitpenyakit tersebut juga berdampak pada orang yang tidak merokok (Aditama, 2015).

Menurut Rahmah dkk (2015), faktor efikasi diri untuk berhenti merokok berkorelasi signifikan dengan intensi berhenti merokok. Berhenti merokok bukanlah perkara yang mudah bagi perokok. Berbagai jenis cara telah dilakukan untuk mengurangi pengonsumsian rokok seperti dengan melakukan penyuluhan akan bahaya rokok, namun hal tersebut kurang efektif apabila tanpa adanya usaha dan keyakinan dari dalam diri untuk berhenti merokok. Usaha dapat ditimbulkan melalui harapan, dimana dalam harapan tersebut termasuk efikasi diri didalamnya yaitu harapan bahwa individu mampu melaksanakan usaha yang diinginkan.

Masih tingginya kasus perokok di Kota Bogor menjadi alasan bagi masyarakat, praktisi kesehatan, dan pemerintah untuk dapat mengambil langkah dan kebijakan yang tepat dalam mencegah meluasnya perokok di Kota Bogor. Sebagai salah satu bidang ilmu, matematika turut memberikan peranan penting dalam mencegah meluasnya perokok yaitu melalui model matematika terkait peningkatan jumlah perokok. Adapun tujuan dari penelitian ini yaitu mengembangkan model matematika dinamika perokok dengan menambahkan faktor efikasi diri, sehingga model matematika yang terbentuk diharapkan dapat menggambarkan dinamika perokok di Kota Bogor pada masa yang akan datang.

\section{Teori dan Model}

Menurut Rahmah (2015) perokok secara umum dibagi menjadi dua tipe, yaitu:

a. Perokok Aktif adalah individu yang memiliki kebiasaan merokok, oleh karena itu perokok aktif akan berupaya untuk mendapatkan rokok.

b. Perokok Pasif adalah individu yang tidak memiliki kebiasaan merokok, tetapi individu tersebut menghirup asap rokok yang dihembuskan oleh orang disekitarnya. Individu tersebut tidak berniat untuk merokok, sehingga jika individu tersebut tidak menghirup asap rokok maka aktivitas yang dilakukan tidak akan terganggu.

\section{Publikasi Ilmiah Matematika}

Menurut Anggraini, dkk (2013), model matematika jumlah perokok dengan dinamika akar kuadrat yang terdiri dari empat kompartemen, yakni perokok potensial $(P)$, perokok kadang-kadang $(L)$, perokok berat $(S)$ dan mantan perokok $(Q)$. Model pertama digunakan interaksi antara perokok potensial dan perokok kadang-kadang, sedangkan model kedua digunakan interaksi antara perokok potensial dan perokok berat.

a. Model matematika jumlah perokok dengan interaksi antara perokok potensial dan perokok kadangkadang.

$$
\begin{aligned}
& \frac{d P}{d t}=\varphi-\beta_{1} \sqrt{P L}-(c+\mu) P \\
& \frac{d L}{d t}=\beta_{1} \sqrt{P L}-(c+\mu+\gamma) L \\
& \frac{d S}{d t}=\gamma L-\left(c+\mu+\delta_{1}\right) S \\
& \frac{d Q}{d t}=\delta_{1} S-(c+\mu)
\end{aligned}
$$

dengan $P, L>0, S, Q \geq 0$ dan $\varphi>0,0<\beta_{1}, c, \mu, \gamma, \delta_{1}<1$. 
Kubik, Vol. 4 No. 1 Edisi Mei 2019

ISSN : 2338-0896

Keterangan:

$\varphi=$ Individu yang berumur 10 tahun

$\mu \quad=$ Kematian secara alami

$c \quad=$ Perokok potensial terkena imbas dari perokok aktif

$\beta_{1}$ = Laju kelompok individu yang memasuki perokok kadang - kadang

$\gamma \quad$ = Laju kelompok individu yang memasuki perokok berat

$\delta_{1} \quad$ = Laju kelompok individu yang memasuki mantan perokok

b. Model matematika jumlah perokok dengan interaksi antara perokok potensial dan perokok berat.

$$
\begin{aligned}
& \frac{d P}{d t}=\varphi-\beta_{2} \sqrt{P S}-(c+\mu) \\
& \frac{d L}{d t}=\beta_{2} \sqrt{P S}-\left(c+\mu+\gamma+\delta_{2}\right) L+\alpha S \\
& \frac{d S}{d t}=\gamma L-(c+\mu+\alpha) \\
& \frac{d Q}{d t}=\delta_{2} L-(c+\mu) Q
\end{aligned}
$$

dengan $P, S>0, L, Q \geq 0$ dan $\varphi>0,0<\beta_{2}, C, \mu, \gamma, \delta_{2}, \alpha<1$.

Keterangan:

$\varphi=$ Individu yang berumur 10 tahun

$\mu=$ Kematian secara alami

$c=$ Perokok potensial terkena imbas dari perokok aktif

$\beta_{2}=$ Laju kelompok individu yang memasuki perokok kadang - kadang

$\gamma=$ Laju kelompok individu yang memasuki perokok berat

$\alpha=$ Laju perpindahan individu dari subpopulasi perokok berat ke subpopulasi perokok kadangkadang

$\delta_{1}=$ Laju kelompok individu yang memasuki mantan perokok

Metode yang digunakan dalam penelitian yaitu mengembangkan model dinamika perokok dari model anggraini dkk 2015, menentukan titik tetap, bilangan reproduksi dasar dan analisis kestabilan, sebagai berikut :

a. Titik tetap

\section{Publikasi Ilmiah Matematika}

Menurut Tu (1993), misal diberikan sistem persamaan diferensial sebagai berikut:

$$
\frac{d x}{d t}=\dot{x}=f(x), x \in R^{n}
$$

Jika titik $\dot{x}$ berada pada bidang $\mathrm{x}$ dengan $f(\dot{x})=0$ maka titik $\dot{x}$ disebut titik tetap.

b. Bilangan reproduksi Dasar

Menurut Hethcote (2000), bilangan reproduksi dasar adalah rata-rata banyaknya individu yang rentan terinfeksi secara langsung oleh individu lain yang telah terinfeksi, bila individu yang telah terinfeksi tersebut masuk kedalam populasi yang seluruhnya masih rentan. Bilangan reproduksi dasar dilambangkan dengan $\Re_{0}$, jika $S_{0}$ yaitu jumlah individu rentan pada saat tidak ada individu yang terinfeksi penyakit dan $\mathrm{S}^{*}$ yaitu jumlah individu rentan pada saat ada individu yang terinfeksi penyakit, maka bilangan reproduksi rasio dirumuskan sebagai berikut:

$$
\mathfrak{R}_{0}=\frac{\mathrm{S}_{0}}{\mathrm{~S}^{*}}
$$

Beberapa kondisi yang akan timbul, yaitu:

1. Jika $\Re_{0}<1$, maka penyakit akan menghilang.

2. Jika $\mathfrak{R}_{0}=0$, maka penyakit menetap.

3. Jika $\Re_{0}>1$, maka penyakit akan meningkat menjadi wabah. 
c. Matriks Jacobian

Menurut Kelley dan Peterson (2010), misal diberikan suatu sistem persamaan:

$$
\begin{gathered}
y_{1}=f_{1}\left(x_{1}, x_{2}, \ldots, x_{n}\right) \\
y_{2}=f_{2}\left(x_{1}, x_{2}, \ldots, x_{n}\right) \\
\vdots \\
y_{n}=f_{n}\left(x_{1}, x_{2}, \ldots, x_{n}\right)
\end{gathered}
$$

maka matriks Jacobian (J) dari sistem persamaan (5) didefinisikan sebagai:

$$
J=\left[\begin{array}{cccc}
\frac{\partial y_{1}}{\partial x_{1}} & \frac{\partial y_{1}}{\partial x_{2}} & \cdots & \frac{\partial y_{1}}{\partial x_{n}} \\
\frac{\partial y_{2}}{\partial x_{1}} & \frac{\partial y_{2}}{\partial x_{2}} & \cdots & \frac{\partial y_{2}}{\partial x_{n}} \\
\vdots & \vdots & \ddots & \vdots \\
\frac{\partial y_{n}}{\partial x_{1}} & \frac{\partial y_{n}}{\partial x_{2}} & \cdots & \frac{\partial y_{n}}{\partial x_{n}}
\end{array}\right]
$$

d. Kriteria Routh-Hurwitz

Menurut Fisher (1990) salah satu metode yang dapat digunakan dalam analisis kestabilan yaitu kriteria Routh-Hurwitz. Misalkan $a_{1}, a_{2}, \ldots, a_{k}$ bilangan-bilangan real dan $a_{j}=0$ jika $j>k$. Semua nilai eigen dari persamaan karakteristik

$$
p(\lambda)=\lambda^{k}+a_{1} \lambda^{k-1}+\ldots+a_{k-2} \lambda^{2}+a_{n-1} \lambda^{1}+a_{k}=0
$$

memiliki bagian real yang negatif jika dan hanya jika determinan dari matriks $A$ berukuran $i \times i$,

$$
A=\left[\begin{array}{ccccc}
a_{1} & a_{3} & a_{5} & \cdots & a_{2 i-1} \\
1 & a_{2} & a_{4} & \cdots & a_{2 i-2} \\
0 & a_{1} & a_{3} & \cdots & a_{2 i-3} \\
\vdots & \vdots & \vdots & \ddots & \vdots \\
0 & 0 & 0 & \cdots & a_{i}
\end{array}\right]
$$

dengan $i=1,2,3, \ldots, n$. Menurut kondisi Routh-Hurwitz, untuk suatu $k, k=2,3,4$ disebutkan bahwa titik tetap $x^{*}$ stabil jika dan hanya jika,

$$
\begin{aligned}
& k=2 ; a_{1}>0, a_{2}>0, \\
& k=3 ; a_{1}>0, a_{3}>0, a_{1} a_{2}>a_{3}, \\
& k=4 ; a_{1}>0, a_{3}>0, a_{4}>0, a_{1} a_{2} a_{3}>a_{3}{ }^{2}+a_{1}{ }^{2} a_{4} .
\end{aligned}
$$

\section{Hasil dan Diskusi Publikasi IImiah Matematika}

Pengembangan model dinamika perokok di Kota Bogor merupakan pengembangan dari model anggraini dkk tahun 2013 dengan menambahkan faktor efikasi diri, diawali dengan penentuan asumsiasumsi, membentuk model matematika dinamika perokok kemudian model yang diselesaikan secara analitik dan numerik untuk simulasi . Adapun asumsi yang digunakan sebagai berikut :

1. Setiap individu perokok potensial dalam populasi memiliki peluang yang sama untuk melakukan kontak dengan individu lain yang sudah menjadi perokok berat,

2. Apabila individu yang berada dalam kelompok perokok potensial $(P)$ melakukan kontak dengan individu perokok kadang-kadang atau perokok berat, maka terdapat dua kemungkinan yaitu individu tersebut langsung dinyatakan masuk ke dalam kelompok individu perokok berat (S) atau masuk ke dalam kelompok individu perokok kadang-kadang $(L)$ terlebih dahulu,

3. Efikasi diri terjadi pada kelompok individu perokok kadang-kadang $(L)$ dan perokok berat $(S)$, sehingga terdapat kemungkinan yaitu individu tersebut langsung dinyatakan masuk ke dalam kelompok individu mantan perokok $(Q)$

4. Kematian individu secara alami terjadi di semua kelompok individu, sedangkan kematian individu akibat merokok terus menerus hanya terjadi pada kelompok individu perokok berat $(S)$, 
5. Individu dalam kelompok mantan perokok $(Q)$ masih memiliki keinginan untuk merokok, sehingga terdapat individu dalam kelompok tersebut yang sewaktu-waktu dapat menjadi perokok aktif kembali dan masuk dalam kelompok individu perokok berat $(S)$,

6. Jumlah populasi $N=P+L+S+Q$ dengan $N$ merupakan populasi tertutup sehingga penambahan atau pengurangan individu dalam populasi hanya terjadi melalui proses kelahiran, kematian, dan adanya faktor efikasi diri, sedangkan penambahan atau pengurangan individu dalam populasi melalui proses migrasi diabaikan.

Berdasarkan asumsi-asumsi tersebut kemudian dibentuk model matematika sebagai berikut :

$$
\begin{aligned}
& \frac{d P}{d t}=\pi-\beta S P-\mu P \\
& \frac{d L}{d t}=f \beta S P-\delta L-\alpha L-\mu L \\
& \frac{d S}{d t}=(1-f) \beta S P+\delta L+\omega Q-\gamma S-\mu S-\mu_{t} S \\
& \frac{d Q}{d t}=\alpha L+\gamma S-\omega Q-\mu Q
\end{aligned}
$$

Keterangan :

$$
\begin{array}{ll}
P(0) & : P_{0} \geq 0, L(0)=L_{0} \geq 0, S(0)=S_{0} \geq 0, Q(0)=Q_{0} \geq 0 \text {, dan } N=P+L+S+Q \\
P & : \text { kelompok individu rentan merokok (perokok potensial) } \\
L & : \text { kelompok individu perokok kadang-kadang } \\
S & : \text { kelompok individu perokok berat } \\
Q & : \text { kelompok individu yang berhenti merokok (mantan perokok) } \\
N & : \text { jumlah populasi keseluruhan }
\end{array}
$$

Parameter-parameter yang digunakan dalam model terdapat pada tabel 1 berikut :

Tabel 1. Parameter yang dipilih untuk menjalankan simulasi numerik

\begin{tabular}{cl}
\hline Parameter & \multicolumn{1}{c}{ Deskripsi } \\
\hline$\pi$ & Laju kelahiran \\
$\mu$ & Lajukematiankasi II m ia h Mate matika \\
$\mu_{t}$ & Laju kematian karena rokok \\
$\beta$ & Laju kontak antara individu kelompok rentan merokok dan \\
& perokok \\
$\delta$ & Laju perpindahan individu dari kelompok perokok kadang (L) \\
& ke kelompok perokok berat (S) \\
$\gamma$ & Laju kesembuhan \\
$\alpha$ & Laju perpindahan individu dari kelompok perokok potensial \\
$\omega$ & (P) ke kelompok berhenti merokok (Q) \\
$f$ & Laju perpindahan individu dari kelompok Q ke kelompok S \\
& Peluang individu perokok potensial akan memasuki periode \\
& perokok kadang kadang
\end{tabular}


1. Penyelesaian Analitik

a. Penentuan Titik Tetap

Dalam penyelesaian analitik diawali dengan penentuan titk tetap, titik tetap pertama ditentukan berdasarkan asumsi dalam populasi tidak terdapat individu yang menjadi perokok berat atau $S=0$, selanjutnya dilakukan penyederhanaan persamaan $\frac{d L}{d t}=0, \frac{d Q}{d t}=0, \frac{d S}{d t}=0$, kemudian disubstitusikan ke dalam $\frac{d P}{d t}=0$, maka diperoleh titik tetap pertama sebagai berikut:

$$
T_{1}=\left(P_{1}, L_{1}, S_{1}, Q_{1}\right)=\left(\frac{\pi}{\mu}, 0,0,0\right)
$$

Titik tetap kedua ditentukan berdasarkan asumsi bahwa dalam populasi terdapat individu yang menjadi perokok berat atau $S \neq 0$, kemudian dilakukan penyederhanaan $\frac{d P}{d t}=0, \frac{d L}{d t}=0, \frac{d Q}{d t}=0$ dan disubstitusi ke dalam persamaan $\frac{d S}{d t}=0$, maka diperoleh titik tetap ke dua sebagai berikut :

Diperoleh titik tetap kedua yaitu

$$
T_{2}=\left(P_{2}, L_{2}, S_{2}, Q_{2}\right)
$$

Dengan :

$$
\begin{gathered}
P_{2}=\frac{\pi\left(-\omega \gamma(\delta+\alpha+\mu)+\left(\gamma+\mu+\mu_{t}\right)(\delta+\alpha+\mu)(\omega+\mu)\right)}{\omega \alpha f \beta \pi+(1-f) \beta \pi(\delta+\alpha+\mu)(\omega+\mu)+\delta f \beta \pi(\omega+\mu)}, \\
f \beta \pi\left(-\gamma \omega(\delta+\alpha+\mu)+\left(\gamma+\mu+\mu_{t}\right)(\delta+\alpha+\mu)(\omega+\mu)\right) \\
\left(\gamma \omega \mu(\delta+\alpha+\mu)+\omega \alpha f \beta \pi-\mu\left(\gamma+\mu+\mu_{t}\right)(\delta+\alpha+\mu)(\omega+\mu)+\right. \\
L_{2}=\frac{(1-f) \beta \pi(\delta+\alpha+\mu)(\omega+\mu)+\delta f \beta \pi(\omega+\mu))}{(\delta+\alpha+\mu)(\omega \alpha f \beta \pi+(1-f) \beta \pi(\delta+\alpha+\mu)(\omega+\mu)+\delta f \beta \pi(\omega+\mu))}, \\
\left(\beta\left(-\gamma \omega(\delta+\alpha+\mu)+\left(\gamma+\mu+\mu_{t}\right)(\delta+\alpha+\mu)(\omega+\mu)\right)\right) \\
S_{2}=\frac{\gamma \omega \mu(\delta+\alpha+\mu)+\omega \alpha f \beta \pi-\mu\left(\gamma+\mu+\mu_{t}\right)(\delta+\alpha+\mu)(\omega+\mu)+}{(1-f) \beta \pi(\delta+\alpha+\mu)(\omega+\mu)+\delta f \beta \pi(\omega+\mu)} \\
\beta\left(-\gamma \omega(\delta+\alpha+\mu)+\left(\gamma+\mu+\mu_{t}\right)(\delta+\alpha+\mu)(\omega+\mu)\right)
\end{gathered}
$$

dan

$$
\begin{gathered}
\left(-\mu\left(\mu+\mu_{t}\right)(\delta+\alpha+\mu)(\omega+\mu)-\mu^{2} \gamma(\delta+\alpha+\mu)+\beta \pi(\delta+\alpha+\mu)(\omega+\mu)-f \beta \pi \alpha \mu-f \beta \pi \mu(\omega+\mu)\right) \\
\left(\alpha f \beta \pi\left(-\gamma \omega(\delta+\alpha+\mu)+\left(\gamma+\mu+\mu_{t}\right)(\delta+\alpha+\mu)(\omega+\mu)\right)+\right. \\
\gamma(\delta+\alpha+\mu)(\beta \pi(\delta+\alpha+\mu)(\omega+\mu)-f \beta \pi \alpha \mu-f \beta \pi \mu(\omega+\mu))))(\omega+\mu)
\end{gathered}
$$

\section{b. Bilangan Reproduksi Dasar $\left(\mathfrak{R}_{0}\right)$}

Berdasarkan pada persamaan (4), maka diperoleh bilangan reproduksi rasio sebagai berikut :

$$
\mathfrak{R}_{0}=\frac{\omega \alpha f \beta \pi+(1-f) \beta \pi(\delta+\alpha+\mu)(\omega+\mu)+\delta f \beta \pi(\omega+\mu)}{\mu\left(-\omega \gamma(\delta+\alpha+\mu)+\left(\gamma+\mu+\mu_{t}\right)(\delta+\alpha+\mu)(\omega+\mu)\right)}
$$

\section{c. Analisis Kestabilan Titik Tetap}

Titik tetap pertama $\left(T_{1}\right)$ dianalisis kestabilannya pada kondisi bebas perokok yaitu saat $\mathfrak{R}_{0}<1$ :

$$
\frac{\omega \alpha f \beta \pi+(1-f) \beta \pi(\delta+\alpha+\mu)(\omega+\mu)+\delta f \beta \pi(\omega+\mu)}{\mu\left(-\omega \gamma(\delta+\alpha+\mu)+\left(\gamma+\mu+\mu_{t}\right)(\delta+\alpha+\mu)(\omega+\mu)\right)}<1
$$

Persamaan (9) diselesaikan menggunakan kriteria Routh-Hurwitz dan jika diketahui bahwa $\pi>0, \beta>0$, $\gamma>0, \delta>0, \mu>0, \mu_{t}>0, \omega>0$ dan $0<f<1$, berdasarkan hasil perhitungan diperoleh bahwa $a_{1}>0, a_{3}>0$ dan $a_{1} a_{2}-a_{3}>0$. Hal ini menunjukkan titik tetap pertama $\left(T_{1}\right)$ stabil di $\mathfrak{R}_{0}<1$, yang berarti bahwa untuk jangka waktu yang lama populasi bebas dari perokok. 
Titik tetap pertama $\left(T_{1}\right)$ dianalisis kestabilannya pada kondisi endemik perokok yaitu saat $\Re_{0}>1$ :

$$
\frac{\omega \alpha f \beta \pi+(1-f) \beta \pi(\delta+\alpha+\mu)(\omega+\mu)+\delta f \beta \pi(\omega+\mu)}{\mu\left(-\omega \gamma(\delta+\alpha+\mu)+\left(\gamma+\mu+\mu_{t}\right)(\delta+\alpha+\mu)(\omega+\mu)\right)}>1
$$

Berdasarkan hasil perhitungan diperoleh bahwa pada kondisi $\mathfrak{R}_{0}>1$ diperoleh $a_{3}<0$ yang menyebabkan tidak terpenuhinya kriteria Routh-Hurwitz, sehingga dapat disimpulkan bahwa titik tetap pertama $\left(T_{1}\right)$ tidak stabil di $\mathfrak{R}_{0}>1$ yaitu pada kondisi endemik perokok. Hal tersebut menunjukkan bahwa titik tetap pertama merupakan titik tetap bebas perokok.

Titik tetap kedua $\left(T_{2}\right)$ dianalisis kestabilannya pada kondisi bebas perokok yaitu saat $\mathfrak{R}_{0}<1$ :

$$
\frac{\omega \alpha f \beta \pi+(1-f) \beta \pi(\delta+\alpha+\mu)(\omega+\mu)+\delta f \beta \pi(\omega+\mu)}{\mu\left(-\omega \gamma(\delta+\alpha+\mu)+\left(\gamma+\mu+\mu_{t}\right)(\delta+\alpha+\mu)(\omega+\mu)\right)}<1
$$

Berdasarkan hasil perhitungan diperoleh bahwa pada kondisi $\mathfrak{R}_{0}<1$ diperoleh $a_{4}<0$ yang menyebabkan tidak terpenuhinya kriteria Routh-Hurwitz, sehingga dapat disimpulkan bahwa titik tetap kedua $\left(T_{2}\right)$ tidak stabil pada saat $\mathfrak{R}_{0}<1$ yaitu pada kondisi bebas perokok. Hal tersebut menunjukkan bahwa titik tetap kedua merupakan titik tetap endemik perokok.

Titik tetap kedua $\left(T_{2}\right)$ dianalisis kestabilannya pada kondisi endemik perokok yaitu saat $\mathfrak{R}_{0}>1$ :

$$
\frac{\omega \alpha f \beta \pi+(1-f) \beta \pi(\delta+\alpha+\mu)(\omega+\mu)+\delta f \beta \pi(\omega+\mu)}{\mu\left(-\omega \gamma(\delta+\alpha+\mu)+\left(\gamma+\mu+\mu_{t}\right)(\delta+\alpha+\mu)(\omega+\mu)\right)}>1
$$

Persamaan (12) diselesaikan dengan kriteria Routh-Hurwitz, karena $\pi>0, \beta>0, \gamma>0, \delta>0, \mu>$ $0, \mu_{t}>0, \omega>0, \alpha>0$ dan $0<f<1$, berdasarkan hasil perhitungan diperoleh bahwa $a_{1}>0, a_{2}>$ $0, a_{3}>0, a_{4}>0$ dan $a_{1} a_{2} a_{3}-a_{1}^{2} a_{4}-a_{3}{ }^{2}>0$. Hal ini menunjukan bahwa titik tetap kedua $\left(T_{2}\right)$ stabil di $\Re_{0}>1$, yang berarti bahwa titik tetap kedua merupakan titik tetap endemik perokok.

\section{Penyelesaian Numerik}

\section{a. Dinamika populasi perokok pada saat $\mathfrak{R}_{0}<\mathbf{1}$}

Untuk melakukan simulasi dinamika populasi perokok di Kota Bogor, diberikan kondisi dengan parameter $\pi=0.8, \mu=0.003, \mu_{t}=0.005, \beta=0.000002, \delta=0.2, \gamma=0.2, \alpha=0.004, \omega=0.2$, dan

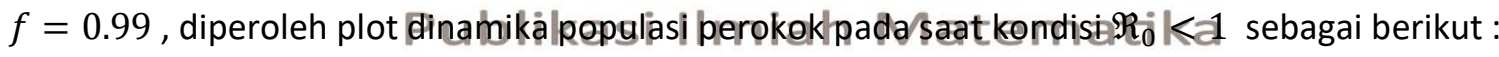

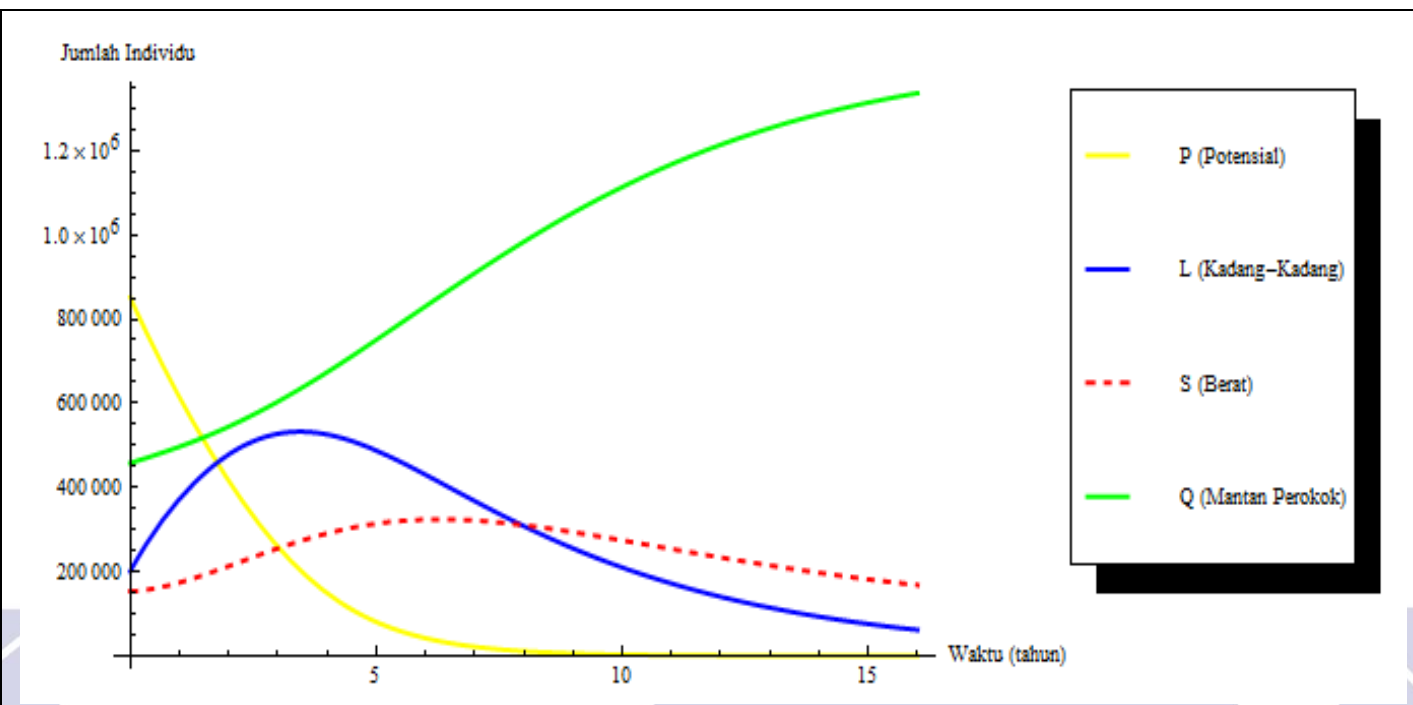

Gambar 1. Dinamika Populasi Perokok saat $\mathfrak{R}_{0}<1$ 
Pada gambar 1 menunjukkan laju perubahan kelompok individu perokok potensial $(P)$, perokok kadang-kadang $(L)$, perokok berat $(S)$, dan mantan perokok $(Q)$. Berdasarkan Gambar 3 dapat dilihat bahwa jumlah perokok kadang-kadang yang ditunjukkan oleh garis berwarna biru mengalami kenaikan mengakibatkan menurunnya jumlah perokok potensial yang ditunjukkan oleh garis berwarna kuning, pada tahun ke 2 laju perokok kadang-kadang berada di atas perokok potensial dengan jumlah individu dan pada tahun ke 8 jumlah perokok kadang-kadang mengalami penurunan mengakibatkan jumlah perokok berat yang ditunjukkan oleh garis patah-patah berwarna merah mengalami kenaikan. Penurunan jumlah individu perokok potensial, perokok kadang-kadang, dan perokok berat mengakibatkan jumlah individu mantan perokok mengalami kenaikan yang signifikan sampai 16 tahun yang akan datang sehingga banyak individu yang terus berupaya untuk berhenti merokok.

\section{b. Dinamika Populasi Perokok saat $\mathfrak{R}_{\mathbf{0}}>\mathbf{1}$}

Pada kasus ini diberikan kondisi dengan nilai parameter $\pi=0.3, \mu=0.0002 \mu_{t}=0.000006$, $\beta=0.00001, \delta=0.001, \gamma=0.035, \alpha=0.01, \omega=0.9$, dan $f=0.99$, diperoleh plot dinamika populasi perokok pada saat kondisi $\Re_{0}>1$ sebagai berikut :

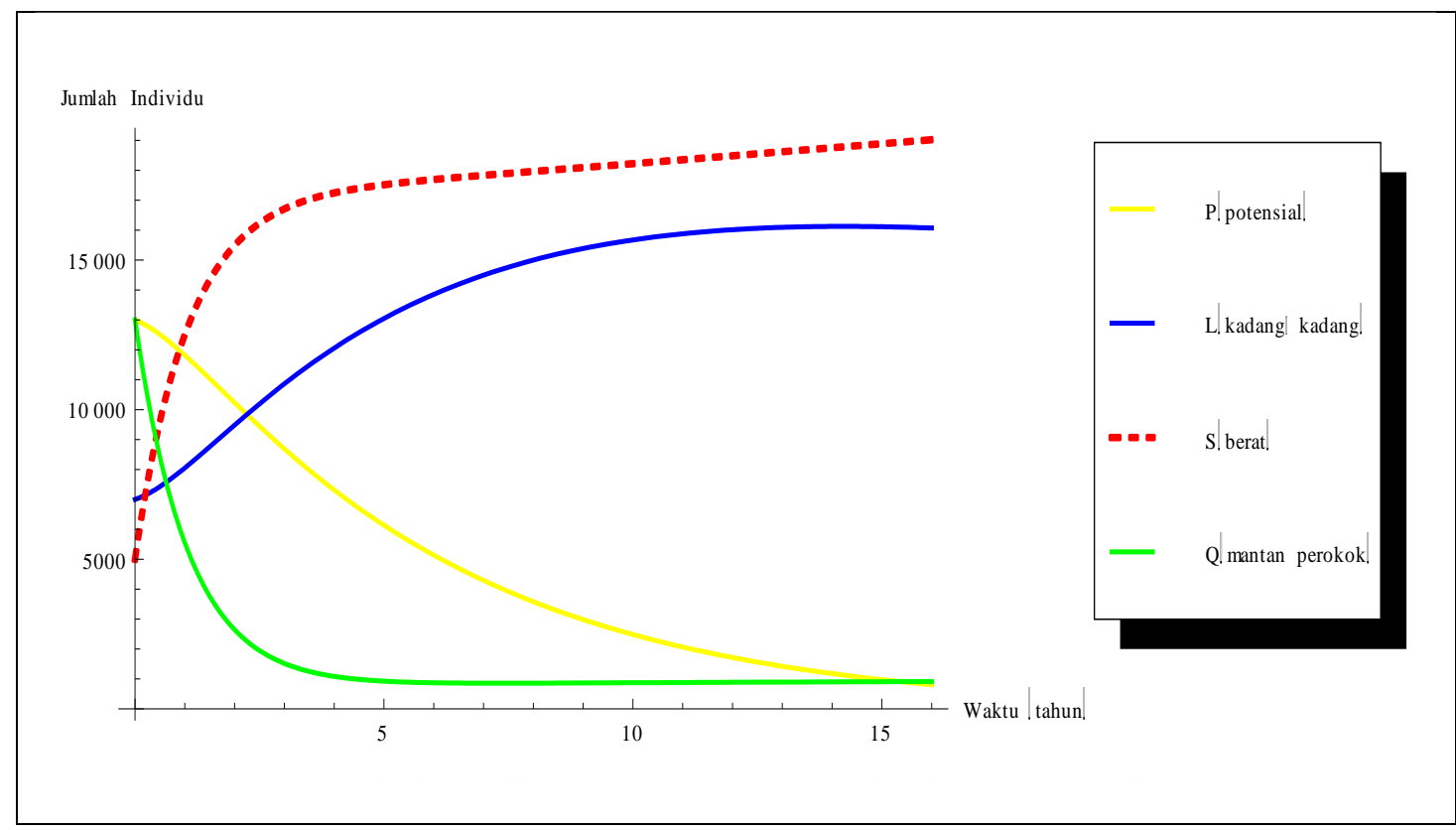

Gambar 2. Dinamika Populasi Perokok saat $\Re_{0}>1$

Pada gambar 2 menunjukkan laju perubahan kelompok individu perokok potensial $(P)$, perokok kadang-kadang $(L)$, perokok berat $(S)$, dan mantan perokok $(Q)$. Berdasarkan Gambar 2 dapat dilihat bahwa jumlah perokok kadang-kadang yang ditunjukkan oleh garis berwarna biru mengalami kenaikan sampai 16 tahun yang akan datang mengakibatkan menurunnya jumlah perokok potensial yang ditunjukkan oleh garis berwarna kuning, pada tahun ke 3 laju perokok kadang-kadang berada di atas perokok potensial dan pada tahun ke 2 jumlah perokok berat yang ditunjukkan oleh garis patah-patah berwarna merah mengalami kenaikan sampai 16 tahun yang akan datang mengakibatkan laju perokok berat berada di atas perokok potensial. Kenaikan jumlah perokok berat mengakibatkan jumlah individu mantan perokok mengalami penurunan sampai 16 tahun yang akan datang tetapi tidak akan mencapai nol sehingga kurangnya motovasi dari dalam diri untuk berhenti merokok. 


\section{Kesimpulan}

Pada saat kondisi bebas perokok di Kota Bogor setelah adanya faktor efikasi diri untuk berhenti merokok, jumlah perokok kadang-kadang akan mendekati nol pada 16 tahun yang akan datang ditandai dengan adanya peningkatan jumlah individu yang berhenti merokok, sedangkan perokok berat mengalami penurunan dari tahun ke 8 hingga 16 tahun yang akan datang. Pada saat kondisi marak perokok, jumlah perokok berat terus meningkat dari tahun ke tahun, jumlah berokok berat berada di atas jumlah perokok potensial dengan jumlah individu pada selang 10.000-15.000 jiwa, kenaikan jumlah perokok berat mengakibatkan jumlah individu mantan perokok mengalami penurunan sampai 16 tahun yang akan datang. Hal ini menunjukkan bahwa setelah adanya faktor efikasi diri untuk berhenti merokok jumlah perokok di Kota Bogor mengalami penurunan tetapi tidak akan mencapai nol.

\section{Referensi}

[1] H. W. Hethcote, "The Mathematics of Infectious Diseases", SIAM Review, Vol. 42, no 4, 2000.

[2] L. Rahmah, F. Sabrian, dan D. Karim, "Faktor Pendukung dan Penghambat Intensi Remaja Berhenti Merokok" , Riau, 2015.

[3] M.V. Anggraini, Miswanto, dan Fatmawati, "Analisis Model Matematika Jumlah Perokok dengan Dinamika Akar Kuadrat", Jurnal Matematika, Vol. 2, 2013, P. 10-20.

[4] N. V. P. Tu, "Dynamical System An Introduction with Application in Economics and Biology", Springer Verlag, Germany. 1994.

[5] S.D. Fisher, "Complex Variable. $2^{\text {nd }}$ Ed", California(US):Wadsworth \& Brooks/Cole Books \& Software. 1990.

[6] T.Y. Aditama, "Masalah Merokok dan Penanggulangannya", Ikatan Dokter Indonesia, Jakarta. 2015.

[7] W.G. Kelley, A.C. Peterson, "The Theory of Differential Equation: Classical and Qualitative", Springer, New York, 2010.

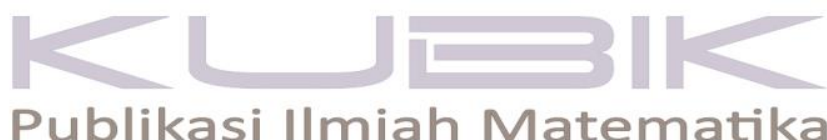

